\title{
SUMMARY
}

GENETIC DETERMINISM OF SEXUAL PRECOCITY, OVULATION RATE

AND NUMBER OF EMBRYOS IN THE SOW : HERITABILITY, HETEROSIS EFFECT

Genetic analysis of the weight, age, ovulation rate and number of embryos at the first cestrus has been made on data obtained from six successive series of animals born in August from I 966 to $197 \mathrm{I}$, respectively, fed ad libitum and submitted to daily heat controls from $70 \mathrm{~kg}$ live weight.

The components of the variance of the first two variables were estimated on the basis of informations collected from 649 purebred sows (60I Large-White and $4^{8}$ Landrace sows born only in I97I), daughters of 65 sires and 233 dams. This number of animals was reduced to 474 for the ovulation rate and $30_{4}$ for the number of embryos, respectively.

The combined effect of year and breed on weight and age at puberty was significant and explained I5.9 and I3.I p. Ioo respectively of the variance. The "sire "effect was significant on the first three variables and explained 9.9, ro. I and $5.7 \mathrm{p}$. Too respectively of the variance. Finally, the "dam " effect was only significant on the two variables representative of sexual precocity and explained $\mathbf{2 2 . 6}$ and 20.0 p. Ioo respectively of the variance. Estimation of the heritability of the four precited variables were : $0.44,0.46,0.23$ and 0.12 , respectively.

Estimations of heterosis effect were made by comparing performances of $24 \mathrm{I}$ purebred sows controlled in 1971 and 1972 to those of 329 contemporary crossbred animals : Landrace male $\times$ Large-White female. Almost inexistent for the weight at puberty, the heterosis effect was about 8 to Io $\mathrm{p}$. Ioo for the age at puberty, $3.5 \mathrm{p}$. Ioo for the ovulation rate and 8 p. Ioo for the number of embryos.

The ovulation rate being not heritable enough and too slightly correlated with the number of embryos it is not possible to obtain a genetic improvement of the second variable by selection of the first one. Finally, the age at puberty is sufficiently heritable to be fitted for efficient selection; however, a more rapid improvement of this character can be obtained by crossbreeding.

\section{EFFET DU CROISEMENT SUR LE TAUX DE RÉUSSITE DE L'INSÉMINATION ARTIFICIELLE CHEZ LA TRUIE. INCIDENCE ÉCONOMIQUE}

\author{
C. LEgAULT, J. GRUAND et J.-P. PROVOST \\ Station de Génétique quantitative et appliquée \\ Centre national de Recherches zootechniques, I. N. R. A., \\ 78350 Jouy en Josas
}

\section{RÉSUMÉ}

Le taux de réussite de l'insémination artificielle à la puberté de I 44 jeunes truies de race pure (dont 96 Large-White et 48 Landrace) et de II 4 jeunes truies issues du croisement mâle Landrace $\times$ femelle Large-White observés dans le cadre d'une étude expérimentale sont respec- 
tivement égaux à o,79 et 0,93 . Cette différence hautement significative traduit un effet d'hétérosis de l'ordre de $18 \mathrm{p}$. Ioo sur ce caractère. Un sondage réalisé à la même époque dans des élevages pratiquant l'insémination artificielle sur I 691 truies de race pure et 194 truies croisées confirme cette tendance avec une différence de l'ordre de 5 points sur le taux de réussite correspondant à un effet d'hétérosis voisin de 8 p. Ioo.

Dans le cadre de l'étude expérimentale, l'amélioration de la fertilité des truies issues de croisement se traduit par une diminution théorique de 5 jours de l'intervalle entre mises bas et une augmentation de la productivité numérique d'environ 0,5 porcelet sevré/truie/an; dans le cadre du sondage réalisé dans les élevages, cette dernière augmentation est nettement plus faible et de l'ordre de 0 , I porcelet.

Cet avantage des croisements vient s'ajouter à ceux qui sont mieux connus au niveau de la. prolificité et la précocité sexuelle.

\title{
SUMMARY
}

\section{EFFECT OF CROSSBREEDING ON THE FERTILIZATION RATE FOLLOWING ARTIFICIAL INSEMINATION IN THE SOW ; ECONOMIC INCIDENCE}

The fertilization rates following artificial insemination of 144 mature pure-bred gilts (96 Large-White and 48 Landrace) and I I 4 crossbred gilts, Landrace male $\times$ Large-White females observed during an experimental study were 0.79 and 0.93 , respectively. This higher significant difference accounts for a heterosis effect of about i 8 p. 100 on this character. An inquiry made at the same period in farms practising artificial insemination (I 69I purebred sows and 194 crossbred sows) confirms this tendency with a difference of about 5 points on the fertilization rate corresponding to a heterosis effect of about $8 \mathrm{p}$. Ioo.

In these experimental conditions, improvement of fertility of crossbred sows resulted in a theoretical reduction or 5 days of the in terval between farrowings and an increase of productivity in the sows (about 0.5 weaned piglet/sow/year). However, this increase was much lower in the conditions of practice (O.I weaned piglet/sow/year).

Consequently, this advantage of crossbreeding can be added to its favourable and well known effect on prolificacy and sexual precocity.

\section{INFLUENCE DE L'ORIGINE PATERNELLE SUR LE NIVEAU GENÉTIQUE DES VERRATS CONTRO̊LÉS INDIVIDUELLEMENT EN 1971}

\author{
M. MOLÉNAT \\ Station de Génétique quantitative et appliquée, \\ Centre national de Recherches zootechniques, I. N. R. A., \\ 78350 Jouy en Josas

\section{RÉSUMÉ}

Une étude publiée en 1972 montrait qu'au niveau des stations de contrôle individuel, l'héritabilité observée était très voisine de l'héritabilité attendue. La présente étude met en évidence l'influence de l'origine des verrats. Il apparaît que les animaux d'origine anglaise donnent 